\title{
Optimization of Aqueous Extraction of Virgin Coconut Oil Using Response Surface Methodology
}

\author{
Ravindra Kumar Agarwal ${ }^{1}$ and S. John Don Bosco ${ }^{2}$
}

\begin{abstract}
The present investigation deals with optimization of aqueous extraction process for maximum yield of virgin coconut oil (VCO) from coconut milk extracted from coconut meat. Optimization of the process parameters including dilution ratio $(\mathrm{w} / \mathrm{w})$, grinding time $(\mathrm{min})$, temperature $\left({ }^{\circ} \mathrm{C}\right)$, cream separation time (hour) and $\mathrm{pH}$ was analyzed using one-factor-at-a-time (OFAT) method and response surface methodology based central composite design methods. OFAT method revealed the dilution ratio of 1:1 and grinding time of 3 min to enhance the yield of VCO whereas central composite design optimized the temperature at $33^{\circ} \mathrm{C}$, cream separation time for 4 hours and $\mathrm{pH}$ of coconut milk at 6.5 for the maximum VCO yield of $20.38 / 100 \mathrm{~g}$ of fresh coconut meat contained $32.82 \mathrm{~g} / 100 \mathrm{~g}$ fat $(\mathrm{w} / \mathrm{w})$. Hence the percentage oil recovery of VCO was found to be 83.12 per cent $(w / w)$ of fat present in fresh coconut meat. The analysis of variance (ANOVA) of central composite design revealed that temperature $(\mathrm{P}<0.05), \mathrm{pH}(\mathrm{P}<0.05)$ and interaction of these two parameters were highly significant for the yield of VCO with the second order model having the co-efficient of determination $\left(\mathrm{R}^{2}\right)$ of 0.97 .
\end{abstract}

Keywords: virgin coconut oil, aqueous extraction process, optimization, response surface methodology

\footnotetext{
${ }^{1}$ Department of Food Science and Technology, Pondicherry University, Pondicherry 605014, India.

${ }^{2}$ Corresponding author: Tel.: 91-9962149233. Email: sjdbosco@yahoo.com
} 


\section{Introduction}

Coconut oil extracted from fresh and mature coconut without chemical treatment or any refining is known as virgin coconut oil (Marina et. al., 2009). During the recent years, virgin coconut oil (VCO) has received much attention due to its superior aroma; flavor and potential health benefits (Villarino et. al., 2007). VCO is rich in medium chain fatty acids (MCFAs) that have been shown to speed up the metabolism and found to have wide application against various microbes such as fungi, bacteria and viruses (German and Dillard, 2004). VCO has considerably more beneficial effects than copra oil since it sustains most of nutrients because no chemical or high heat treatment is carried out on oil extraction and lowers the lipid level in serum and tissues (Nevin and Rajamohan, 2004).

Coconut milk is used as a raw material for VCO production mainly consists of $23.84 \%$ fat, $2.29 \%$ protein, $5.54 \%$ carbohydrates, $3.34 \%$ sugar and $67.62 \%$ moisture (US Department of Agriculture, 2011). The existing process of producing VCO is principally conducted through the extraction of oil from coconut milk. Coconut milk can be extracted by grinding fresh coconut meat without additional water or with water. It is oil in water emulsion formed from the aqueous extraction of coconut solid endosperm. The emulsion is relatively unstable due to large droplet size (Nattapol and Coupland, 2008) and poor emulsifying properties of coconut protein absorbed at oil-water interface (Onsaard et. al., 2005). The emulsion stabilized by globular protein (albumin and globulin) is often destabilized by changing temperature and $\mathrm{pH}$ of coconut milk emulsion (Nattapol and Coupland, 2005). The effect of heating on the bulk proteins of coconut milk has been studied earlier (Peamprasart and Cheiwchan, 2006).

Aqueous Extraction Process (AEP) is a traditional method used for extraction of VCO from coconut milk (Madhvan et. al., 2005). AEP, wherein water is used as an extraction and separation medium, has regained considerable interest during the past decade as an environmental friendly approach for extraction of oil from oil sources. However, extraction of oil by AEP is based on the insolubility of oil in water rather than on the dissolution of oil (Johnson and Lusas, 1983; Rosenthal, 1996). In this case, the water soluble components of oil diffuse in water rather than in oil thereby releasing the oil which was previously bound in the original structure. The additional benefit of AEP is the capability for use of certain chemicals to take away or deactivate undesirable substances. The unit operation used in AEP may vary with different oleaginous materials but generally consists of grinding, solid-liquid separation, demulsification, centrifugation and drying (Hagenmaieret al. 1972, 1973; Cater et. al., 1974).

Aqueous extraction of oil by varying dilution ratio, $\mathrm{pH}$ adjustment, time and temperature (without any enzyme, physical or chemical treatment) offer some advantages such as no enzyme requirement, low energy requirement and mild operating condition etc. (Rhee et. al., 1973 ).

When many factors and interactions affect desirable response, Response Surface Methodology (RSM) is an effective tool for optimizing processes (Rustom et. al., 1991). RSM takes interactions into consideration and optimizes the process parameters to reasonable range, with the advantage of the relevant information in the shortest time with the least number of experiments (Lee et. al., 2006). The basic principle behind RSM analysis is to relate the observed value (response) to process parameters (independent variables) using statistical methods (Myers and Montgomery, 2002).

The present study aimed at optimization of AEP for extraction of Virgin Coconut Oil from coconut milk by varying the extraction parameters such as dilution ratio (coconut meat/ water ratio), $\mathrm{pH}$, temperature $\left({ }^{\circ} \mathrm{C}\right)$, grinding time (min.) and cream separation time (hour). The research experiments optimized each variable based on traditional "one-factor-at-a-time" method in order to approximate an optimum level of variables. Hence, the Central Composite Design (CCD) was applied to find the optimum 
level of variable for aqueous extraction of $\mathrm{VCO}$ from coconut milk for the well understanding of the special effects of each variable and interactions between them.

\section{Materials and Methods}

\section{Materials}

Fresh and mature (10-12 months old) coconuts (Cocos nucifera L.) of East coast tall variety procured from a local garden of Pondicherry (India). Coconuts were randomly selected for each experiment. All chemical reagents of analytical grade were procured from Merck chemicals, Mumbai, India.

\section{Sample preparation}

Coconut milk was extracted from the fresh mature pared coconut kernel. The testa was removed by using kitchen peeler. The white coconut kernels were disintegrated into small pieces and ground with distilled water in the ratio of $1: 1$ to $1: 4(\mathrm{w} / \mathrm{w})$ in mixer grinder (Crompton Greaves, India) for different time. The model of grinder is having 3 jars, 6 blade, $18,000 \mathrm{rpm}$ and power consumption of $750 \mathrm{~W}$. The grinded coconut mixture was filtered through double layered cheesecloth and pressed manually to obtain coconut milk from the residue.

\section{Aqueous extraction of VCO from coconut milk}

The aqueous extraction of VCO was carried out in $250 \mathrm{ml}$ separating funnel holding of coconut milk extracted based on dilution ratio and incubated for 20-24 hours at various temperature ranging between 25 and $45^{\circ} \mathrm{C}$ and $\mathrm{pH}$ from 4 to 8 . The coconut milk extracted from different dilution ratio $(\mathrm{w} / \mathrm{w})$ for different grinding time ( $\mathrm{min}$ ), was left to settle for 2, 4, 6 hours. The extraction of VCO from the coconut milk was optimized for various parameters using one-factor-at-a-time (OFAT) method and central composite design (CCD).

\section{Percentage oil recovery}

The percentage oil recovery was calculated as the yield of oil from coconut milk extracted from $100 \mathrm{~g}$ of fresh coconut meat through aqueous extraction process divided by oil extracted from fresh coconut meat through official AOAC Soxhlet method (AOAC, 1997).

The formula for the calculation of oil recovery is as below.

$$
\% \text { oil recovery }=\frac{\mathrm{A}}{\mathrm{B}} \times 100
$$

$\mathrm{A}=$ Weight of oil extracted from fresh coconut meat by AEP

$\mathrm{B}=$ Weight of oil extracted from fresh coconut meat - Weight of oil extracted from wet residue by Soxhlet method

\section{Experimental design and statistical analysis}

Optimization using one-factor-at-a time method

The influence of dilution ratio (coconut meat: distilled water), grinding time, $\mathrm{pH}$, temperature, and settling time were investigated with OFAT method for approximate optimization. Dilution ratio was varied from 1:0 (control), 1:1 to $1: 4(\mathrm{w} / \mathrm{w})$; grinding time from 1 to 4 min. The optimized dilution ratio and grinding time through OFAT method were taken for further approximate optimization of VCO extraction at $\mathrm{pH}$ varied as $4,4.5,5,5.5,6,6.5,7$, 8 for the temperature varied from 25 to $40^{\circ} \mathrm{C}$ at $5^{\circ} \mathrm{C}$ interval and variation in settling time of 2 , $3,4,5$ and 6 hours.

To determine the effect of $\mathrm{pH}$ on the extraction of virgin coconut oil from fresh coconut milk, the coconut milk was extracted by grating the meat with acetate buffer ( $\mathrm{pH} 4.5$ to 5) and phosphate buffer (pH 5.5 to 8.0) solutions.

\section{Optimization using the central composite design}

The central composite design was used to optimize exact temperature (A), settling time (B) and $\mathrm{pH}(\mathrm{C})$ for the maximum production of VCO followed by the approximate optimization by the OFAT method. These three variables (A, B and C) at five-level was optimized for aqueous extraction of VCO from coconut milk extracted from fresh coconut meat using CCD. 
According to the CCD, a set of 20 experiments with six replications of center points were executed (Table 1) and their observations were fitted to the following second order polynomial equation (Liu et. al, 2008).

$$
\begin{aligned}
\mathrm{Y}= & \beta_{\mathrm{o}}+\beta_{1} \mathrm{~A}+\beta_{2} \mathrm{~B}+\beta_{3} \mathrm{C}+\beta_{11} \mathrm{~A}^{2}+\beta_{22} \mathrm{~B}^{2}+\beta_{33} \\
& \mathrm{C}^{2}+\beta_{12} \mathrm{AB}+\beta_{13} \mathrm{AC}+\beta_{23} \mathrm{BC} \ldots \ldots \ldots \ldots \text { (1) }
\end{aligned}
$$

Where $\mathrm{Y}$ is the response Yield of VCO g/100g fresh pared coconut meat; temperature (A), separation time (B) and $\mathrm{pH}(\mathrm{C})$ are the independent variables,

$\beta_{\mathrm{o}}$ is the regression coefficient at center point,

$\beta_{1}, \beta_{2}$ and $\beta_{3}$ are the linear coefficients,

$\beta_{11}, \beta_{22}$ and $\beta_{33}$ are the quadratic coefficients,

$\beta_{12}, \beta_{13}$ and $\beta_{23}$ is the second order interaction coefficient.

A statistical software Design-Expert 8.0.7.1 trial (State-Ease Inc., Minneapolis, USA) was used to obtain the coefficients of the quadratic polynomial model. The quality of the fitted model was expressed by the coefficient of determination $R^{2}$, and its statistical significance was checked by $F$-test. By keeping two variables at their central levels, RS plot and contour plots of two factors against oil yield were drawn. Analysis of variance (ANOVA) was performed to evaluate the adequacy of the generated mathematical models. Test of significant fixed for $5 \%$.

Triplicate experiments were carried out at all designed points except at the central point $(0$, $0,0)$, where six replications were performed to allow the estimations of "pure error". All experiments were carried out in randomized order to minimize the effect of unexplained variable on the observed responses due to extraneous factors.

The uncoded and coded levels of the independent variables were examined at five different level (relatively low (-2), low (-1), medium $(0)$, high $(+1)$, relatively high $(+2)$ in CCD as listed in Table 2.

\section{Results and discussion}

\section{Optimization using traditional one -factor at - a- time (OFAT) method}

The first phase of the study was involved in approximate optimization of processing parameters including dilution ratio, grinding time, $\mathrm{pH}$, temperature and cream separation time for maximum yield of VCO through Aqueous extraction process (AEP) using OFAT method. The yield of VCO with the variation of dilution ratio is presented in Fig. 1. The maximum yield of $\mathrm{VCO}$ at $18.92 \mathrm{~g} / 100 \mathrm{~g}$ from fresh coconut meat was observed with 1:1 dilution ratio when compared to the yield of VCO at 18.09, 13.17 and $12.53 \mathrm{~g} / 100 \mathrm{~g}$ from fresh coconut meat with the dilution ratio of $1: 2,1: 3$ and $1: 4$, respectively (Fig. 1a). The significant effect of dilution on increasing the yield of $\mathrm{VCO}$ was observed as compared to the minimum yield of VCO of $15.90 \mathrm{~g} / 100 \mathrm{~g}$ from coconut meat without dilution (1:0). Therefore, the optimal dilution ratio of $1: 1$ improved the yield of VCO, but any further decrease and increase in dilution ratio showed a significant inhibitory effect $(\mathrm{P}<0.05)$. The inhibitory effect of dilution ratio more or less than 1:1 might be attributed to the hindering effect on extraction of coconut oil and other extractable materials owing to insufficient fluidity for grinding while there was the requirement of more time to break the emulsion for lower dilution ratio (1:0). Rhee and others (1972) has reported the effect of dilution ratio on extraction of peanut oil from peanut at the dilution ratio ranging from $1: 5$ to $1: 12$ and Embong and Jelen (1977) also reported the extraction of rape seed oil from rape seed at the dilution ratio from 1:2.5 to 1:3.5.

The grinding time for extraction of coconut milk extracted at 1:1 dilution ratio was examined at different levels ranging from one minute to four minutes. The maximum yield of VCO of $20.1 \mathrm{~g} / 100 \mathrm{~g}$ coconut meat was found for 3 minutes of grinding time whereas for 1,2 , and 4 minutes of grinding time, the yield of $\mathrm{VCO}$ were $17.8,18.6$ and $18.7 \mathrm{~g} / 100 \mathrm{~g}$ coconut meat, respectively (Fig. 1b). The result of maximum yield of $\mathrm{VCO}$ for grinding time of 3 minutes necessitates the effective grinding to be taken 
place to break down the cell wall of oil cell and coalescence of oil droplets resulting in the formation of greater amount of free oil following centrifugation. The excess grinding produces smaller oil globules result in formation of an emulsion with greater stability which make demulsification more difficult. On the other hand, insufficient grinding responsible for losses of oil in the residue (Hagenmaier et. al., 1972).

On account of the effect of $\mathrm{pH}$ on the yield of VCO, different random levels of $\mathrm{pH}$ as 4.0, $4.5,5.0,5.5,6.0,6.5,7.0$ and 8.0 were investigated the result was presented in Fig. 1c. The maximum oil recovery ranging from $14.09 \mathrm{~g}$ to $19.76 / 100 \mathrm{~g}$ of fresh coconut meat was found between $\mathrm{pH} 5.5$ and 7.5. Since the effect of $\mathrm{pH}$ is expressed with the influence of temperature, the $\mathrm{pH}$ range from 5.5 to 7.5 , found to increase the yield of oil in the present study, was further optimized through CCD. The maximum yield of VCO of was obtained at $\mathrm{pH} 6.5$, but any further increase or decrease of $\mathrm{pH}$ showed an inhibitory effect.

Fig. (1d) depicts the significant effect of temperature ranging from $25^{\circ} \mathrm{C}$ to $40^{\circ} \mathrm{C}$ on the yield of VCO. The maximum yield of VCO of 18.25 and $17.10 \mathrm{~g} / 100 \mathrm{~g}$ of coconut meat was observed at $30^{\circ} \mathrm{C}$ and $35^{\circ} \mathrm{C}$ respectively. Since there was no significant difference between the recovery of VCO for 30 and $35^{\circ} \mathrm{C}$, the optimum temperature for the higher yield of VCO was further investigated through CCD. The extraction of oil dependent on temperature has been shown in the extraction of pea nut oil at temperature ranging from 60 to $65^{\circ} \mathrm{C}$ (Rhee et. al., 1972) and the extraction of palm oil at $40-$ $45^{\circ} \mathrm{C}$ (Kim, et. al., 1989).

From the effect of cream separation time varied from 1 hour to 6 hours, the maximum yield of VCO of $19.22 \mathrm{~g} / 100 \mathrm{~g}$ of coconut meat was observed for 4 hours. The increase in the yield of VCO was observed gradually up to 4 hours and then reduced to 18.66 and $18.11 \mathrm{~g}$ for 5 and 6 hours, respectively as shown in Fig. 1e. Hence, dilution ratio of 1:1 and grinding time of 3 minutes were approximately optimized for the maximum yield of VCO. Since $\mathrm{pH}$, temperature and cream separation time were observed to directly influence the yield of VCO through OFAT method; these variables were exactly optimized using CCD.

\section{Optimization using central composite design (CCD)}

Table 1 depicts the experimental levels of yield of VCO obtained from 20 combinations of 5 levels $(-2,-1,0,+1,+2)$ of independent variables such as $\mathrm{pH}$, temperature and separation time which were shown to be required for optimization through CCD, based on the results of OFAT method in the first phase of the study. The experimental levels of oil yield were used to generate a second order polynomial model capable of predicting the optimal point of the yield of VCO mathematically within the experimental constraints, as a function of temperature (A), separation time (B) and $\mathrm{pH}(\mathrm{C})$ using Design-Expert 8.0.7.1 trial (State-Ease Inc., Minneapolis, USA).

$$
\begin{aligned}
\mathrm{Y}= & 20.29+0.59 \mathrm{~A}+0.20 \mathrm{~B}+0.27 \mathrm{C}+0.52 \mathrm{AB}+ \\
& 0.25 \mathrm{AC}+0.31 \mathrm{BC}-1.59 \mathrm{~A}^{2}-0.83 \mathrm{~B}^{2}- \\
& 0.99 \mathrm{C}^{2} \ldots \ldots \ldots \ldots \ldots \ldots \ldots \ldots \ldots \ldots \ldots \ldots \ldots \ldots \ldots \ldots \ldots \ldots \ldots \ldots \ldots \ldots \ldots \ldots \ldots
\end{aligned}
$$

The regression model was used to calculate the predicted values of VCO yields and compared with experimental values. The total determination coefficient $\left(\mathrm{R}^{2}\right)$ was 0.976 explaining the $97.6 \%$ of variability in the yield of VCO depends on the effect of independent variables ( $\mathrm{A}, \mathrm{B}$ and $\mathrm{C}$ ) of the study and evidencing the quality of fit of the model (Fig. 2). The value of adjusted coefficient of determination $(95.42 \%)$ and adequate precision (signal to noise ratio) 22.7 were also high indicating the significance of the model. Adequate precision measures the signal to noise ratio and observed to be 22.664 which is greater than 4 indicating this model can be used to navigate the design space.

From ANOVA table, the statistical analysis of the model showed the significance and adequacy of the model for which, the $\mathrm{F}$ value was 45.0 (Table 3 ). According to the linear coefficients of $\mathrm{A}, \mathrm{B}$ and $\mathrm{C}$, the significant positive effect of $\mathrm{A}$ and $\mathrm{C}$ was shown on response (Y) whereas the quadratic and interactive effects of $\mathrm{A}, \mathrm{B}$ and $\mathrm{C}$ were shown to 
be significant on the yield of $\operatorname{VCO}(\mathrm{P}<0.01)$ meaning that they could act as limiting conditions and little variation in their magnitude would alter the yield of VCO. The coefficient of variation $(\mathrm{CV})$ of the model was calculated to be $2.68 \%$ in which less than $10 \%$ representing a better precision and reliability of the model (Daniel, 1991).

The 3D and 2D contour plots were drawn to predict the yield of $\mathrm{VCO}$ with an interactive effect of A, B and C as shown in Fig. 3, 4, and 5. The combined effect of temperature (A) and separation time (B) on the yield of VCO is shown in Fig. 3. A linear effect of both the A and $\mathrm{B}$ on the response was observed. The maximum yield of VCO was predicted to be $20.38 \mathrm{~g} / 100 \mathrm{~g}$ coconut meat at $33^{\circ} \mathrm{C}$ temperature for 4 hours of separation time $(\mathrm{P}<0.05)$ and the percentage oil recovery of VCO was found to be 83.12 percent of fat $(32.82 \mathrm{~g} / 100 \mathrm{~g})$ in fresh coconut meat. Fig. 4 depicts the interactive effect of temperature (A) and $\mathrm{pH}(\mathrm{C})$ on the yield of VCO. The maximum yield of VCO was predicted to be $20.38 \mathrm{~g} / 100 \mathrm{~g}$ coconut meat at $33^{\circ} \mathrm{C}$ temperature and $\mathrm{pH}$ of $6.5(\mathrm{P} \leq 0.05)$.

The joint effect of separation time (B) and $\mathrm{pH}(\mathrm{C})$ on the yield of VCO is shown in Fig. 5. There was the maximum yield of VCO (20.38 $\mathrm{g} / 100 \mathrm{~g}$ fresh coconut meat) with the linear effect of both the separation time of 4 hours and $\mathrm{pH}$ of 6.5 on the yield of VCO $(\mathrm{P}>0.05)$. Hence, it could be explored that the extraction conditions of $33^{\circ} \mathrm{C}$ temperature, $\mathrm{pH}$ of 6.5 and separation time of 4 hours were found to be optimal for maximum yield of VCO (20.38 g/100g fresh coconut meat).

\section{Conclusion}

The present study reveals the effective use of response surface methodology based central composite design method followed by onefactor-at-a-time (OFAT) method in the optimization of process parameters for aqueous extraction of virgin coconut oil from coconut milk. Results showed that the optimization of dilution ratio at 1: 1 for the grinding time of 3 minutes to enhance the yield of VCO from OFAT method and further optimization of temperature at $33^{\circ} \mathrm{C}, \mathrm{pH}$ at 6.5 and cream separation time of $4 \mathrm{~h}$ to the maximum $\mathrm{VCO}$ yield of $20.38 \mathrm{~g} / 100 \mathrm{~g}$ fresh coconut meat using central composite design with the significant interactive effect of temperature and cream separation on the yield of VCO with the oil recovery of VCO found to be 83.12 percent of fat in fresh coconut meat. These results help in optimization of the aqueous extraction process for the maximum oil recovery of VCO.

\section{Acknowledgements}

The author sincerely thank to the Department of Food and Technology, Pondicherry University for providing laboratory facilities.

\section{References}

AOAC Official methods of analysis. 1997. Association of Official Agricultural Chemist (17 $7^{\text {th }}$ ed.). Washington DC.

Cater, C.M., K.C. Rhee, R.D. Hagenmaier and K.F. Mattil. 1974. Aqueous extraction-an alternative oilseed milling. J. Am. Oil Chem. Soc. 51: 137-141.

Daniel, W.W. 1991. Biostatistics: A foundation for analysis in the health sciences. $\left(5^{\text {th }} \mathrm{ed}\right.$.) Wiley: New York.

Embong, M.B. and P. Jelen. 1977. Technical feasibility of aqueous extraction of rapeseed oil-a laboratory study. J. Inst. Can. Sci. Technol. Aliment. 10: 239-243.

German, J.B. and C.J. Dillard. 2004. Saturated fats: what dietary intake? American Journal of Clinical Nutrition 80: 550-559.

Hagenmaier, R.D., C.M. Cater and K.F. Mattil. 1973. Aqueous processing of fresh Coconuts for recovery of oil and coconut skim milk. Journal of Food Science 38: 516-518.

Hagenmaier, R.D., C.M. Cater and K.F. Mattil. 1972. Critical unit operations of the aqueous processing of fresh coconuts. $J$. Am. Oil Chem. Soc. 49: 178-181.

Johnson, L.A. and E.W. Lusas. 1983. Comparison of alternative solvents for oils 
extraction. J. Am. Oil Chem. Soc. 60: 229242.

Kim, H.K. 1989. Aqueous extraction of oil from palm kernel. J. Food Sci., 54: 491-492.

Lee, W.C., S. Yusof, N.S.A. Hamid, and B.S. Baharin. 2006. Optimizing conditions for Hot Water Extraction of banana juice using response surface methodology (RSM). Journal of Food Engineering 75 (4): 473-479.

Liu, S., F. Yang, C. Zhang, H. Ji, P. Hong and C. Deng. 2009. Optimization of process parameters for supercritical carbon dioxide extraction of Pass flora seed oil by response surface methodology. Journal of Supercritical Fluids 48: 9-14.

Madhavan, K., S.N. Kumar, and S. Azeez. 2005. Virgin coconut oil by fermentation method. Indian Coconut Journal 4:8-9.

Marina, A.M., Y.B. Che Man and I. Amin. 2009. Virgin coconut oil: emerging functional food oil. Trends Food Sci Technol. 20: 481-487.

Myers, R. and D.C. Montgomery. 2002. Response surface methodology. Wiley: New York, USA.

Nattapol, T. and J.N. Coupland. 2005. Effect of heating and homogenization on the stability of coconut milk emulsions. Journal of Food Science 70 (8): 466-470.

Nattapol, T. and J.N. Coupland. 2008. Effect of surface-active stabilizers on the microstructure and stability of coconut milk emulsions. Food Hydrocolloids 22: 1233-1242.

Nevin, K.G. and T. Rajamohan. 2004. Beneficial effects of virgin coconut oil on lipid parameters and in vitro LDL oxidation. Clin Biochem 37: 830-835.

Onsaard, E., M. Vittayanont, S. Sringam, and D.J. Mc Clements. 2005. Properties and stability of oil-in-water emulsions stabilized by coconut skim milk proteins. J. Agric. Food Chemistry 53 (14): 574753.
Peamprasart, T., and N. Chiewchan. 2006. Effect of fat content and preheat treatment on the apparent viscosity of coconut milk after homogenization. Journal of Food Engineering 77: 653-658.

Rhee, K.C., C.M. Cater, and K.F. Mattil. 1972. Simultaneous recovery of protein and oil from raw peanuts in an aqueous system. $J$. Food Sci. 37: 90-93.

Rhee, K.C., Cater, C.M. and Mattil, K.F. 1973. Effect of processing $\mathrm{pH}$ on the properties of peanut protein isolates and oil. Cereal Chem. 50: 395-404.

Rosenthal, A., D.L. Pyle, and K. Niranjan. 1996. Aqueous and enzymatic processes for edible oil extraction. Enzyme Microbial Technology 19: 402-420.

Rustom, I.Y.S., M.H. Lopez-Leiva, and B.M. Nair. 1991. A study of factors affecting extraction of peanut (Arachis hypogaea L.) solids with water. Food Chemistry 42: 153-165.

US Department of Agriculture, Agricultural Research Service. 2001. USDA Nutrient Database for Standard Reference Release 14. US Department of Agriculture. USA.

Villarino, B.J., L.M. Dy, and M.C.C. Lizada. 2007. Descriptive sensory evaluation of virgin coconut oil and refined, bleached, deodorized coconut oil. LebensmittelWissenschaft und Technologie (LWT) 40: 193-199. 
Table 1. Central composite design (CCD) matrix for RSM showing experimental and predicted Yield of Virgin coconut oil from coconut milk extracted from $100 \mathrm{~g}$ of fresh coconut meat

\begin{tabular}{|c|c|c|c|c|c|}
\hline \multirow{3}{*}{$\begin{array}{l}\text { Rum } \\
1\end{array}$} & \multicolumn{3}{|c|}{ Coded Value } & \multirow{2}{*}{\multicolumn{2}{|c|}{$\begin{array}{c}\text { Oil Yield }^{\mathrm{a}}(\%) \\
\text { (g of VCO/ } 100 \mathrm{~g} \text { fresh coconut meat) } \\
\text { Experimental Value Predicted value }\end{array}$}} \\
\hline & $\mathbf{A}$ & B & $\mathbf{C}$ & & \\
\hline & -1 & -1 & -1 & 16.34 & 16.90 \\
\hline 2 & 1 & -1 & -1 & 17.03 & 16.54 \\
\hline 3 & -1 & 1 & 1 & 15.62 & 15.64 \\
\hline 4 & 1 & 1 & 1 & 16.99 & 17.36 \\
\hline 5 & -1 & -1 & 1 & 16.31 & 16.32 \\
\hline 6 & 1 & -1 & 1 & 16.60 & 16.97 \\
\hline 7 & -1 & 1 & 1 & 15.43 & 16.30 \\
\hline 8 & 1 & 1 & 1 & 19.20 & 19.03 \\
\hline 9 & -2 & 0 & 0 & 13.30 & 12.75 \\
\hline 10 & 2 & 0 & 0 & 14.96 & 15.12 \\
\hline 11 & 0 & 2 & 0 & 16.60 & 16.56 \\
\hline 12 & 0 & 2 & 0 & 17.70 & 17.35 \\
\hline 13 & 0 & 0 & -2 & 15.84 & 15.80 \\
\hline 14 & 0 & 0 & 2 & 17.24 & 16.90 \\
\hline 15 & 0 & 0 & 0 & 20.36 & 20.29 \\
\hline 16 & 0 & 0 & 0 & 20.38 & 20.29 \\
\hline 17 & 0 & 0 & 0 & 20.37 & 20.29 \\
\hline 18 & 0 & 0 & 0 & 20.34 & 20.29 \\
\hline 19 & 0 & 0 & 0 & 20.35 & 20.29 \\
\hline 20 & 0 & 0 & 0 & 20.34 & 20.29 \\
\hline
\end{tabular}

avalues are average of three determinations $(n=3)$

$\mathrm{A}=$ Temperature $\left({ }^{\circ} \mathrm{C}\right), \mathrm{B}=$ Separation time (hour), $\mathrm{C}=\mathrm{pH}$

Table 2. Coded and uncoded levels of independent variables used in CCD matrix for yield of VCO

\begin{tabular}{cccc}
\hline \multirow{2}{*}{$\begin{array}{c}\text { Coded levels of } \\
\text { independent variable }\end{array}$} & \multicolumn{3}{c}{ Un-coded value of independent variable } \\
\cline { 2 - 4 } & $\begin{array}{c}\text { Temperature }\left({ }^{\circ} \mathbf{C}\right) \\
(\mathbf{A})\end{array}$ & $\begin{array}{c}\text { Separation time (h) } \\
(\mathbf{B})\end{array}$ & $\begin{array}{c}\text { pH } \\
(\mathbf{C})\end{array}$ \\
\hline 2 & 41 & 6 & 7.5 \\
1 & 37 & 5 & 7.0 \\
0 & 33 & 4 & 6.5 \\
-1 & 29 & 3 & 6.0 \\
-2 & 25 & 2 & 5.5 \\
$\Delta \mathrm{X}$ & 4 & 1 & 0.5 \\
\hline
\end{tabular}


Figure 1. Yield of $\mathrm{VCO}(\mathrm{g} / 100 \mathrm{~g}$ of coconut meat) with variation of (a) dilution ratio, (b) grinding time (c) initial $\mathrm{pH}$, (d) temperature and (e) cream separation time when parameters were fixed as: Dilution ratio 1:1 (w/w); grinding time 3 minutes, initial $\mathrm{pH} \quad 6.0$ (unadjusted), temperature $33^{\circ} \mathrm{C}$ and cream separation time 6 hours.

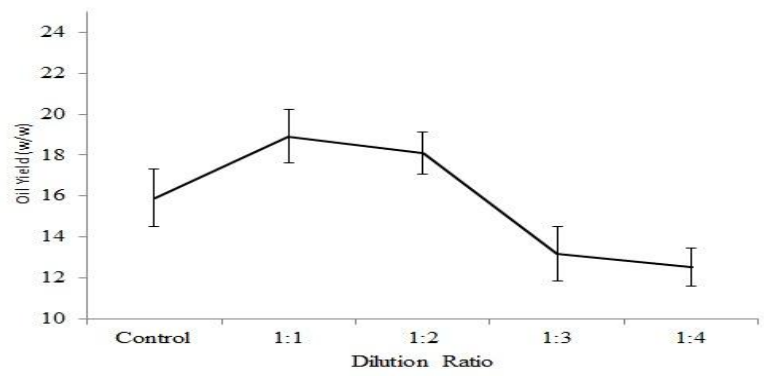

Figure 1(a). Yield of VCO at different dilution ratio when $\mathrm{pH}$, incubation temperature and cream separation time were maintained 6.0 (unadjusted), $33^{\circ} \mathrm{C}$ and 4 hours, respectively.

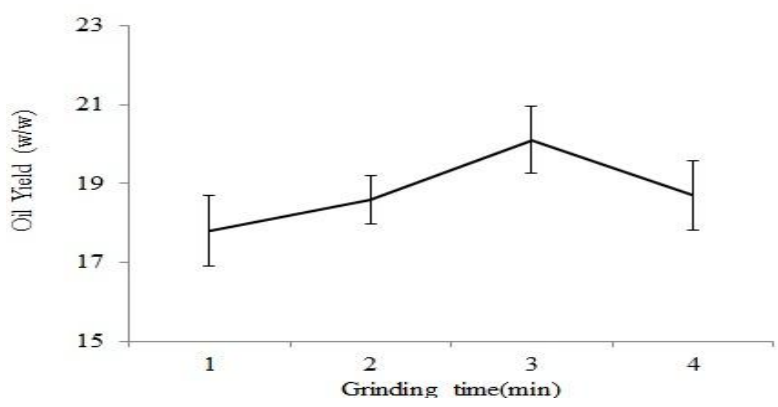

Figure 1(b). Yield of VCO at different grinding time (minute) when $\mathrm{pH}$, incubation temperature, cream separation time and dilution ratio were maintained 6.0 (unadjusted), $33^{\circ} \mathrm{C}, 4$ hours and $1: 1$ respectively.

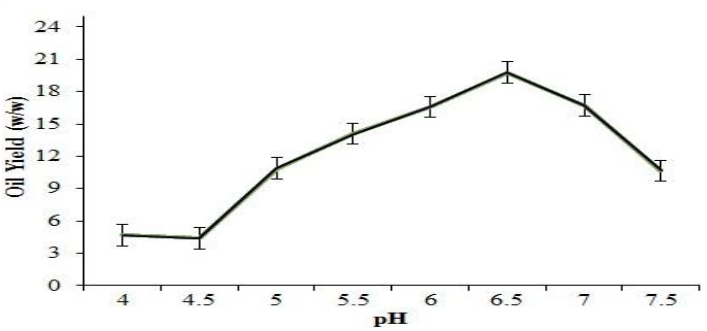

Figure 1(c). Yield of VCO at different $\mathrm{pH}$ when incubation temperature, cream separation time, grinding time and dilution ratio were maintained $33^{\circ} \mathrm{C}, 4$ hours, 3 minutes and 1:1 respectively.

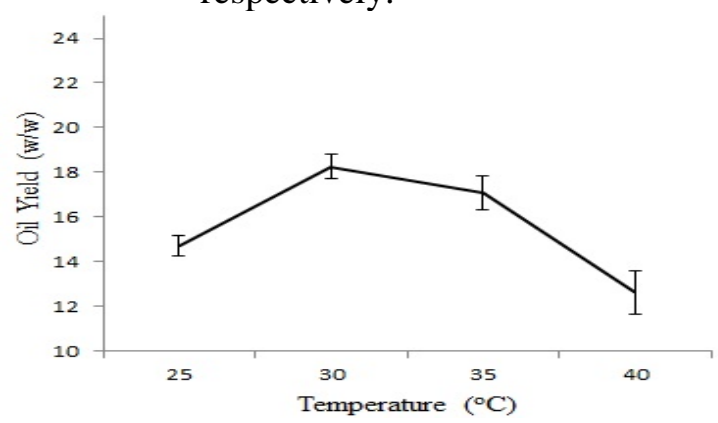

Figure 1(d). Yield of VCO of different temperature (C) when $\mathrm{pH}$, cream separation time, grinding time and dilution ratio were maintained 6.0 (unadjusted), 4 hours, 3 minutes and 1:1 respectively.

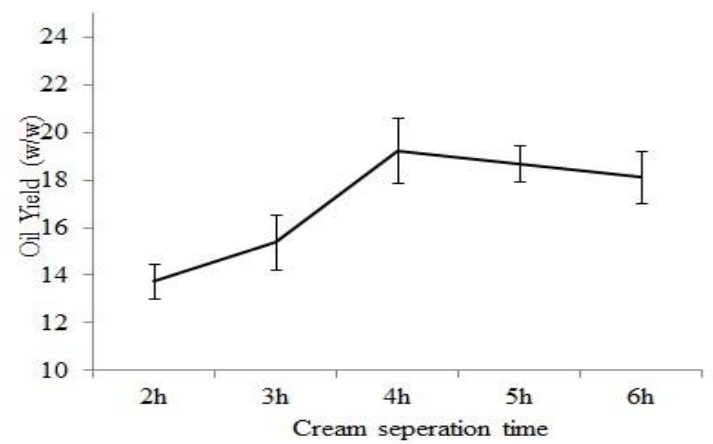

Figure 1(e). Yield of VCO at different cream separation time when incubation temperature, $\mathrm{pH}$, grinding time and dilution ratio were maintained $33^{\circ} \mathrm{C}, 6.0$ (unadjusted), 4 hours, 3 minutes and 1:1 respectively. 
Figure 2. Comparison between predicted and actual value of oil yield (g/100g of coconut meat)

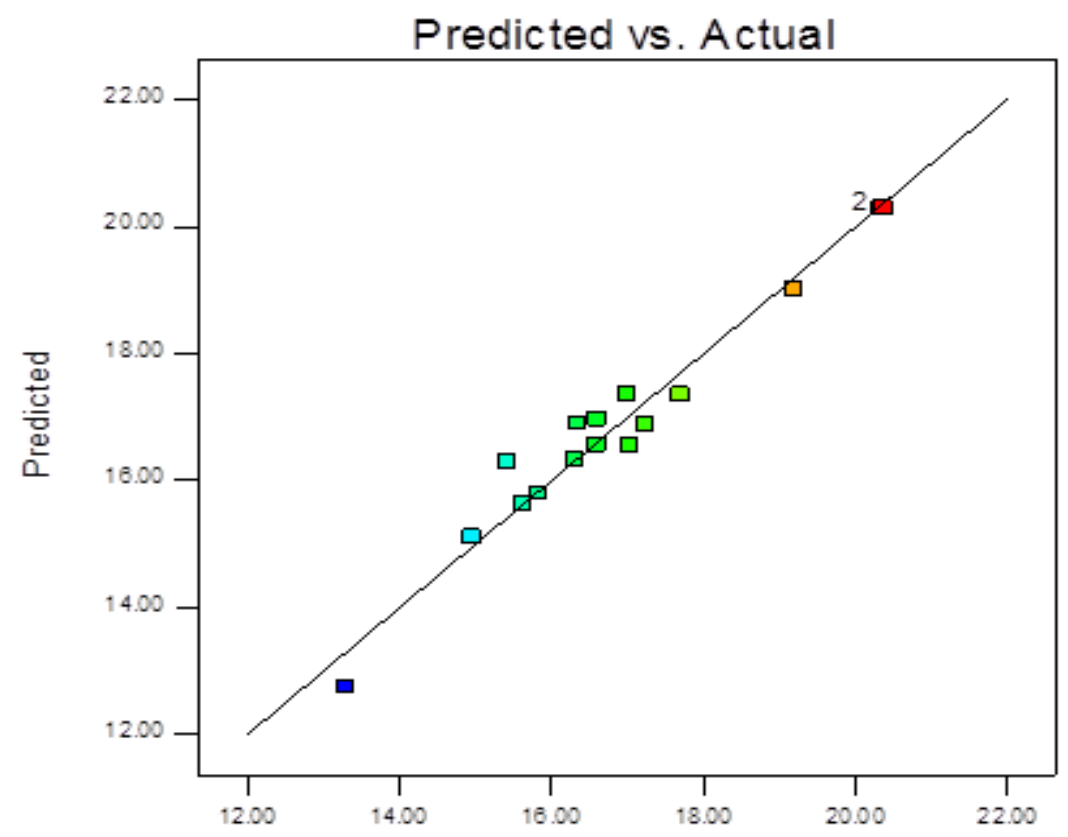

Actual

Table 3. Analysis of variance (ANOVA) results for control composite design (CCD) quadratic model for the response

\begin{tabular}{|l|r|r|r|r|r|}
\hline \multicolumn{1}{|c|}{ Source } & \multicolumn{1}{c|}{$\begin{array}{c}\text { Sum of } \\
\text { Square }\end{array}$} & DF & Mean square & F value & \multicolumn{1}{c|}{ P value } \\
\hline Model & 89.26 & 9 & 9.92 & 45.0 & $<0.0001^{* *}$ \\
A [Temperature ( ${ }^{\circ}$ ) $]$ & 5.59 & 1 & 5.59 & 25.37 & $0.0005^{*}$ \\
B [Sep. time (hour)] & 0.63 & 1 & 0.63 & 2.84 & 0.1228 \\
C [pH] & 1.19 & 1 & 1.19 & 5.40 & $0.0424^{*}$ \\
AB & 2.16 & 1 & 2.16 & 9.78 & $0.0107^{*}$ \\
AC & 0.50 & 1 & 0.50 & 2.26 & 0.1635 \\
BC & 0.77 & 1 & 0.77 & 3.48 & 0.0918 \\
$\mathrm{~A}^{2}$ & 63.52 & 1 & 63.52 & 288.22 & $<0.0001^{* *}$ \\
$\mathrm{~B}^{2}$ & 17.51 & 1 & 17.51 & 79.44 & $<0.0001^{* *}$ \\
$\mathrm{C}^{2}$ & 24.43 & 1 & 24.43 & 110.85 & $<0.0001^{* *}$ \\
R-square & 0.9759 & & 0.44 & 1764.44 & $<0.0001^{* *}$ \\
Adj. R-square & 0.9542 & & & \\
Adequate-precision & 22.714 & & & & \\
Residual & 2.21 & & & & \\
\end{tabular}

$* * \mathrm{p}<0.01$ indicate the model are highly significant

$* \mathrm{p}<0.05$ indicate the model are significant 
Figure 3. 3D response surface plot (a) and 2D contour plot (b) shows the interactive effect of incubation temperature $\left({ }^{\circ} \mathrm{C}\right)$ and cream separation time $(\mathrm{h})$ on the yield of $\mathrm{VCO}(\mathrm{g} / 100 \mathrm{~g}$ of coconut meat)

(a)

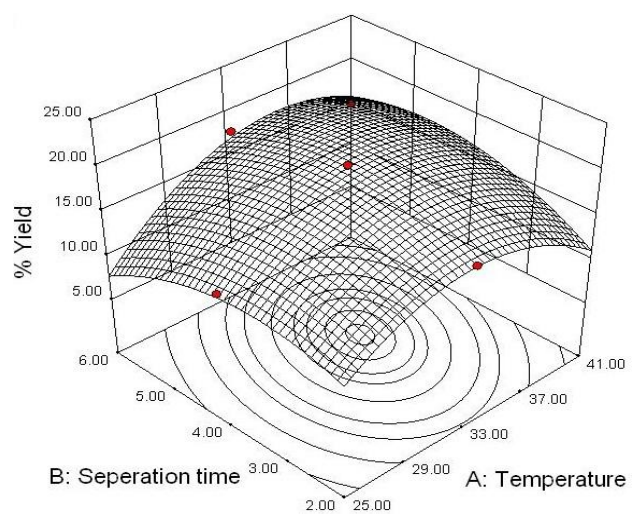

(b)

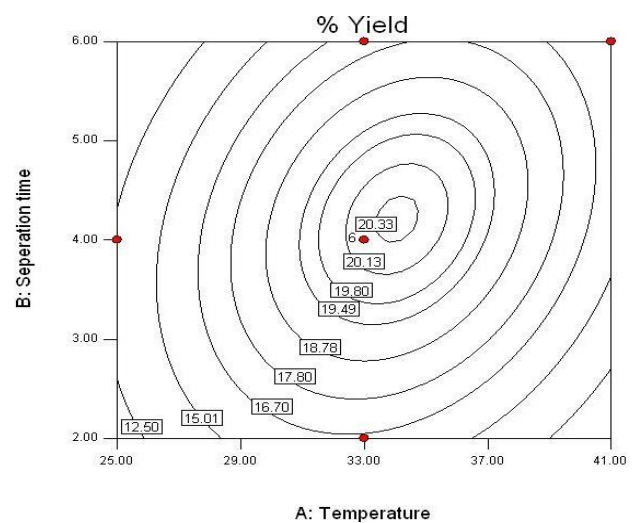

Figure 4. 3D response surface plot (a) and 2D contour (b) plot shows the interactive effect of incubation temperature $\left({ }^{\circ} \mathrm{C}\right)$ and $\mathrm{pH}$ on the yield of $\mathrm{VCO}(\mathrm{g} / 100 \mathrm{~g}$ of coconut meat)

(a)

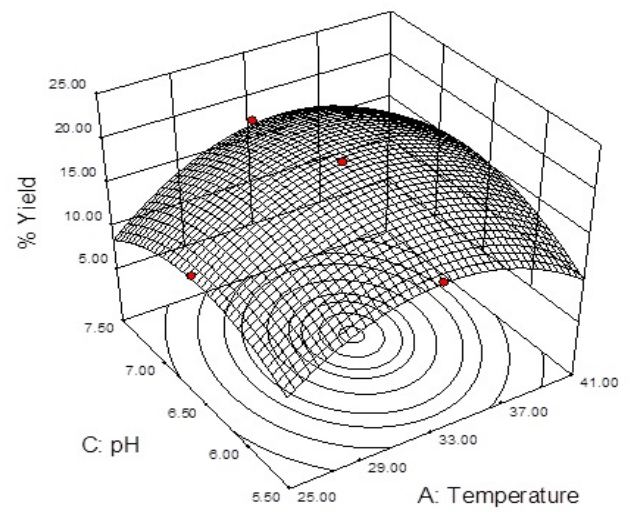

(b)

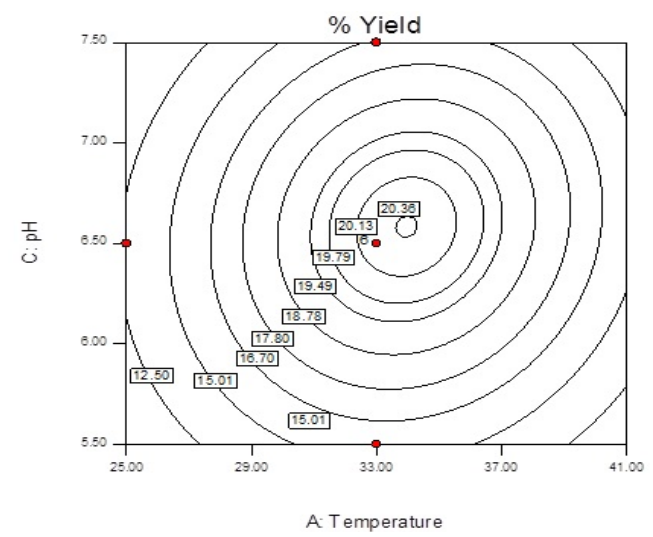

Figure 5. 3D response surface plot (a) and $2 \mathrm{D}$ contour plot (b) shows the interactive effect of creamseparation time $(\mathrm{h})$ and $\mathrm{pH}$ on the yield of $\mathrm{VCO}(\mathrm{g} / 100 \mathrm{~g}$ of coconut meat)

(a)

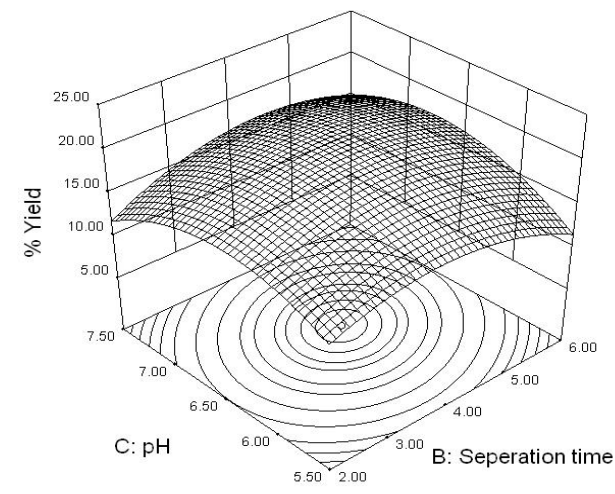

(b)

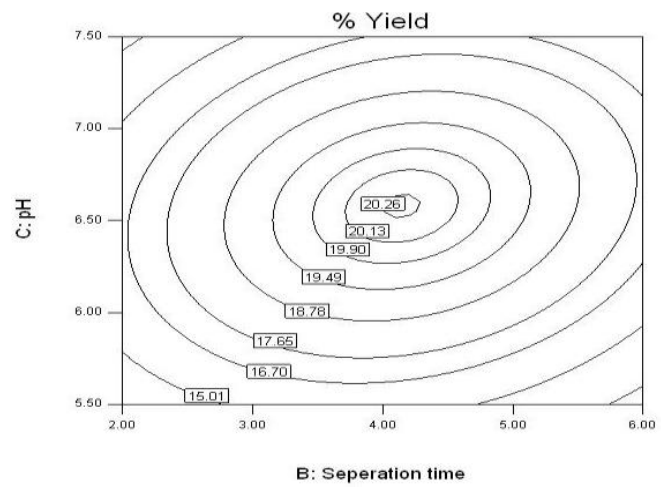

